\title{
Empowerment of Women in Self Help Groups with Emphasis on Goa and Karnataka
}

\author{
Faye Xavier Colaco, Gopinathan N.
}

\begin{abstract}
Women are integral to a country's society as well as its human resource capital. If given equal opportunity as its male counterpart, women with their capabilities will help lead to immense overall development. Women empowerment is seen as a means for women to have control over their lives and make their own choices and decisions to their benefit. Women empowerment has therefore been found to be the key towards development of countries. In this paper, an attempt is made to compare the influence of four dimensions namely Materials change, Cognitive change, Perceptual change and Related change on overall empowerment of women and the comparison between two states namely Goa and Karnataka. Theoretical sampling was used in this study. A total of 263 samples were collected through a survey which was administered to SHG members, group interviews and observation. Measurement Model is used to access the reliability which is termed as the Internal consistency as per Smart PLS literature and validity as per Hair et al. (2014). Validity of the Instrument is accessed through Convergent validity and Discriminant validity. Also, a multigroup analysis is made on the overall model based on two groups namely Goa and Karnataka.
\end{abstract}

Keywords : Empowerment, women, SHG's, Goa, Karnataka, members

\section{INTRODUCTION}

In any country, Women are integral to its society as well as its human resource capital. If given equal opportunity as its male counterpart, women with their capabilities will help lead to immense overall development. In olden times, women were treated justly and equal to men and were even decision makers along with men. But the segregation between men and women arose with the start of mass production and additional revenue due to the need for labour with more muscle power and therefore men were offered better wages and women were forced to do house chores and ultimately being unpaid labour. This kind of disparity is still prevalent even today in various fields and in areas education, health, politics and management positions, employment, household decision making, family property rights, etc. This then has led to women being confined to the household and being dependant on its male family members who have become the main bread winners. Therefore, in India, even though the country has gained

Revised Manuscript Received on July 22, 2019.

Faye Xavier Colac, Assistant Professor, Sri Sri Institute of Management Studies, Goa, India, fayexavier06@yahoo.co.in

Gopinathan N., Associate Professor, VIT Business School, VIT University, Chennai-127, gopinathan.n@vit.ac.in independence from foreign rulers, the study of socio and economic data post-independence has shown that women are comparatively at a disadvantage to their male counterparts in various areas like survival, nutrition and health, education and literacy and productivity which has thus lead to the need for women empowerment.

The World Bank has defined Empowerment as 'the process of enhancing the capacity of individuals or groups to make choices and to transform those choices

into desired actions and outcomes'. Also, it can be understood as increase of resources and skills of poor people to partake in, exert control and hold liable organizations that affect their lives. It helps each person by offering choices and allowing them to make choices for themselves and determine the outcomes of their choices. And it can therefore mean that empowerment is making a informed change. It brings about both sides of development with changing the circumstances of which poor people live in and assisting them to make use of their own qualities to their advantage. From nutrition, health and education to political and government policy, these activities that are a means to empower marginalised people are expected to improve quality of life, increase betterment opportunities and its outcomes. Therefore, empowerment leads to overall development as well and not just at a nuclear level.

\section{LITERATURE REVIEW}

Why have women empowerment gained so much of importance and is a universal goal? We will address this question before defining women's empowerment. The fundamental principle of women's empowerment is of providing financial and economic security to women as well as progressive changes in the areas of health, nutrition and education status of women and children. As reflected in Mason KO, 2003, positive demographic changes especially with regards to fertility and mobility have been seen due to the women's empowerment. Worldwide studies have also revealed positive outcomes due to empowerment. Studies of empowerment programs as described below are evidence to it.

The assessment of the BRAC program by (Schuler, Hashemi1994) established that empowered women due to the access to microcredit which was measured by physical mobility, economic security, autonomous decision making, exposure to violence, political and legal awareness and political participation as well associated 
with increase in contraceptives used.

The Ishraq program as described by USAID education, life skills and basic livelihood trainings along with physical activity to increase social networking and boost self-confidence. The study revealed that the program led to a decline in support for violence against women that included female genital cutting as well a reduction in child marriages and thus led to positive attitude towards women and better fertility behaviours.

Access to microcredit did not make a significant change in the material wellbeing of individuals but seemed to have led to empowerment at three levels. At the individual level, women had enhanced self-confidence, improved status and took up gender biased roles as well. At the household level, women exerted power over small and large household assets, took decisions regarding live hood improvement and even took up jobs further away from homes. And thirdly, at the community level, women took up leadership roles and stood up against ill treatment by banks and evils like polygamy etc.

The importance of empowerment of women can therefore be understood and the need to understand the term empowerment is equally important.

\section{A. Empowerment Defined}

The concept of empowerment has not been defined as a statement and is a new term used in most gender centric literature. The term empowerment essentially means the identification of the full and multidimensional potential of women towards shaping their individual future and of the society at large. At the New York Millennium Summit 2000, Women Empowerment and Gender Equality were identified as significant elements for achieving progress and were accepted as one of its eight millennium goals (Bhagayalakshmi 2004).

A general understanding of empowerment by Dr.DasarathiBhuyan states that it can be divided into two broad areas which is general and specific. In the general sense, empowerment of women to be self-reliant by having access to means and opportunities that were denied due to gender biases. In a specific sense, empowerment of women should lead to enhanced positions of women in the power structure of the society and community.

Women empowerment is seen as a means for women to have control over their lives and make their own choices and decisions to their benefit. With various policies and developmental activities undertaken by the authorities to equip women with many skill sets, empowerment can also be measured in terms of social, economic, political, cultural and technological constructs.Wallerstein (1992) identified empowerment as "people assuming control and mastery over their own lives in the context of their social and political environment. Many other researchers describe empowerment as a process to widen the scope for choice and action of women through skill enhancement. Many others have defined it as control of assets control over assets (Goetz and Sen Gupta 1996); women having freedom to movement, economic security, reduced domination, political awareness and participation in public protests and political campaigns (Hashemiet al. 1996); decision making over household resources (Amin and Pabley 1994); skill based income generation and right over income (Mustafa et al. 1996); household decision-making participatiom (Mizan 1993, Kabeer 2001)

In India, the Constitution grants equality to women with measures to ensure biases towards women through policies, plans, programmes and laws for their advances in different spheres. India has also looked at securing rights of women and has led to the development of Non-Government Organisations (NGOs) for inspiring initiatives for women empowerment. Women have become more aware of their rights and have started standing up for themselves but there still exists a wide gap between the goals laid down by the authority and the ground realities of women in India which is usually measured through declining female ratio, domestic and societal violence, girl child discrimination etc. still exists in most parts of the country. Also, more inequality is seen in rural and backward sections and still they remain largely marginalised and excluded.

\section{B. Self Help Groups(SHG's)}

To assist marginalised women to overcome their lives of poverty and present them with an opportunity to improve their status, Self Help Groups evolved. SHG's provided a way for women to come together and try to tackle obstacles together. It became a way for women to have access to training for skill development, to have access to microcredit as the group became the collateral etc. It was observed by Vijay D Kulkarni (2001) that SHG members fared better than non-members on the empowerment index.

Empowerment through SHG's has started in the area of obtaining economic security (Shanthi\&Dhanalakshmi, 2004) with its core elements being defined as agency which is the ability to define one's goals and achievement of the same, awareness of the societal power structures, self-esteem and confidence(Kabeer,2001)

The National Bank for Agriculture and Rural Development of India(NABARD) has stated that a SHG is a group of similar minded individuals who are economically backward and from rural areas who join together voluntarily to save a part of their earnings and contribute to a common fund to make loans available to members for productive and urgent needs (NABARD, 1995).

Most often, SHG's are formed with 10 to 15 
women to join together with a common goal on a voluntary basis. The group has access to bank credit that is focussed on marginalised and under privileged sections of society (Kashyap, 2001). SHG's have evolved to be a way to combat poverty, empower its members to achieve their potential and have self-confidence, positive changes in their personal, social and economic fronts, and improve their skill sets and managerial capabilities and overall community importance. This being unique to SHG's and not observed in existing groups or organisations (Stiglitz, 1993)

\section{Statement of Problem}

Identification of which particular dimension i.e. Material change, Cognitive change, Perceptual change or Related change has a significant impact on empowering women and the relation between Goa and Karnataka.

D. Objectives of the study

- To compare the influence of four dimensions Materials Change, Cognitive change, Perceptual change and Related change on overall empowerment of women

- To find out the comparison between two states namely Goa and Karnataka

\section{E. Hypothesis}

Null Hypothesis (Ho): There is no significant difference between the dimensions viz. Material change, Cognitive Change, Perceptual change and related change and empowerment of Women.

Alternate Hypothesis (Ha): There is a significant between the dimensions viz. Material change, Cognitive Change, Perceptual change and related change and empowerment of Women.

Null Hypothesis (H1): There is no significant difference between the dimensions viz. Material change, Cognitive Change, Perceptual change and related change and empowerment of Women in Goa and Karnataka

Alternate Hypothesis (Ha2): There is a significant between the dimensions viz. Material change, Cognitive Change, Perceptual change and related change and empowerment of Women in Goa and Karnataka

\section{F. Research Methodology}

A total of 263 samples were collected through a survey which was administered to SHG members, group interviews and observation. Snow ball sampling was used for respondent selection due to smaller sample size.Each dimension has a small list of questions, for which answers were collected on a five point Likert scale The exclusive women SHG's were studied with 134 respondents being from Goa and 129 respondents from Karnataka. The demographic profile of the survey respondents can be understood from Table 1 and 2 in the annexure below. Post analysis findings were drawn on women empowerment and the relation between dimensions as well as between the states of Goa and Karnataka.

\section{DATA ANALYSIS}

The table below infers to the demographic profile of respondents. It is noted that, 54.4 per cent of the respondents were aged above 41 years followed by 38.4 percent of the respondents in the age group between 31-40 years and 7.2 percent between 20-30 years of age. With reference to location, 51 percent were from Goa and 49 percent from Karnataka. Relating to educational qualification it was found that, 53.6 percent of the respondents have qualification less than 10th followed by 25.5 percent below 5th, 11 percent with other qualifications and 9.9 percent had PUC as their qualification. With regard to marital status, 92.8 percent are married when compared to their 7.2 percent counterparts. When it comes to family earners, 77.6 percent of the family have single income followed by 19.4 percent with double income and 3 percent with multi earnings. Family income wise classification showed that, 60.1 percent of the respondents had more than Rs. 10,000 as family income followed by 39.9 percent with less than Rs. 10,000 as family income. While looking into the Association of respondents with SHG's it was found that, 70.3 percent of the respondents had association of more than 4 years with SHG's followed by 18.6 percent of respondents with 3 to 4 years, 6.5 percent with 2- 3 years, 3.8 percent with 1-2 years and 0.8 percent of the respondents with less than 1 year of experience.

Table1: Demographic Profile

\begin{tabular}{|c|c|c|c|}
\hline & & Count & $\begin{array}{l}\text { Column } \\
\mathrm{N} \%\end{array}$ \\
\hline \multirow{3}{*}{$\begin{array}{l}\text { Age of the } \\
\text { Respondents }\end{array}$} & 20-30 years & 19 & $7.2 \%$ \\
\hline & $31-40$ years & 101 & $38.4 \%$ \\
\hline & $\begin{array}{l}\text { Above } 41 \\
\text { years }\end{array}$ & 143 & $54.4 \%$ \\
\hline \multirow[b]{2}{*}{ State } & Karnataka & 129 & $49.0 \%$ \\
\hline & Goa & 134 & $51.0 \%$ \\
\hline \multirow[b]{2}{*}{ Family } & Joint Family & 58 & $22.1 \%$ \\
\hline & $\begin{array}{l}\text { Nuclear } \\
\text { Family }\end{array}$ & 205 & $77.9 \%$ \\
\hline \multirow{4}{*}{$\begin{array}{l}\text { Educational } \\
\text { Qualification }\end{array}$} & Below 5th & 67 & $25.5 \%$ \\
\hline & Below 10th & 141 & $53.6 \%$ \\
\hline & Till PUC & 26 & $9.9 \%$ \\
\hline & Others & 29 & $11.0 \%$ \\
\hline \multirow{2}{*}{ Marital Status } & Married & 244 & $92.8 \%$ \\
\hline & Unmarried & 19 & $7.2 \%$ \\
\hline \multirow{2}{*}{ Family Earners } & $\begin{array}{l}\text { Single } \\
\text { Income }\end{array}$ & 204 & $77.6 \%$ \\
\hline & $\begin{array}{l}\text { Double } \\
\text { Income }\end{array}$ & 51 & $19.4 \%$ \\
\hline
\end{tabular}


Empowerment of Women in Self Help Groups with Emphasis on Goa and Karnataka

\begin{tabular}{|l|l|l|l|} 
& $\begin{array}{l}\text { Multi } \\
\text { Earnings }\end{array}$ & 8 & $3.0 \%$ \\
\hline \multirow{4}{*}{ Family Income } & $<10,000$ & 105 & $39.9 \%$ \\
\cline { 2 - 4 } & $>10,000$ & 158 & $60.1 \%$ \\
\hline \multirow{4}{*}{$\begin{array}{l}\text { Association with } \\
\text { SHG }\end{array}$} & $0-6$ months & 0 & $0.0 \%$ \\
\cline { 2 - 4 } & 6-12 months & 2 & $.8 \%$ \\
\cline { 2 - 4 } & 1-2 Years & 10 & $3.8 \%$ \\
\cline { 2 - 4 } & 2-3 Years & 17 & $6.5 \%$ \\
\cline { 2 - 4 } & $3-4$ Years & 49 & $18.6 \%$ \\
\cline { 2 - 4 } & $>4$ Years & 185 & $70.3 \%$ \\
\hline
\end{tabular}

Source : Primary Survey

\section{A. Measurement Model}

Measurement Model is used to access the reliability which is termed as the Internal consistency as per Smart PLS literature and validity as per Hair et al. (2014). With regard to reliability, the first step is to access the loadings of items in its respective factor which is expected to be more than 0.5 as suggested by (Hulland,1999). It was found from the table that; all the items have loadings more than 0.5 . The second approach is to consider the Cronbach's alpha value for reliability, which is suggested to be more than 0.7 as suggested by Nunnally. As per the analysis, it was found that almost all the values have values more than 0.7. The final approach is to consider the composite reliability score which has to be more than 0.70 . From the analysis it was found that, all the constructs have composite reliability scores more than 0.70 . Hence the instrument was found to be reliable.

Figure1: Measurement Model- Empowerment

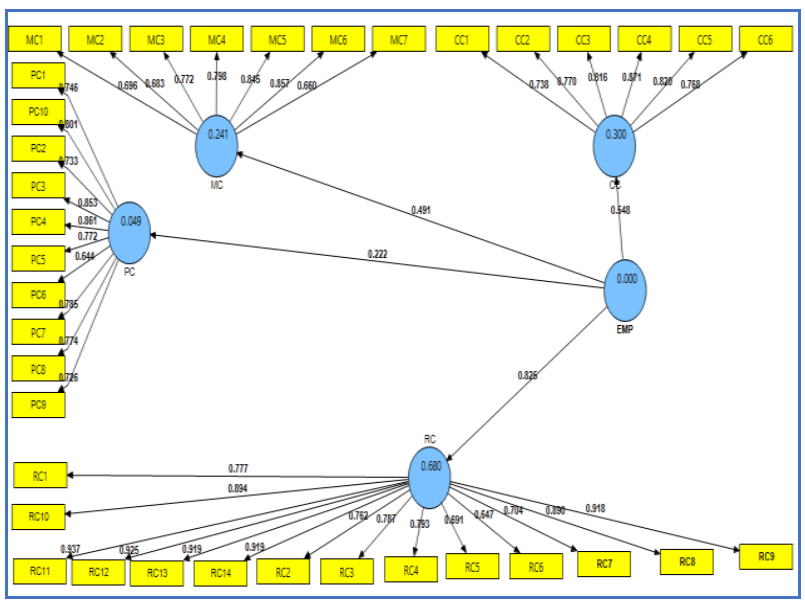

Source : Primary Survey

Table2: Measurement Model- Reliability and Validity

\begin{tabular}{|c|c|c|c|c|c|}
\hline $\begin{array}{l}\text { First order } \\
\text { Constructs }\end{array}$ & Items & $\begin{array}{l}\text { Outer } \\
\text { Loadings }\end{array}$ & $\begin{array}{l}\text { Cronbach's } \\
\text { alpha }\end{array}$ & $\begin{array}{l}\text { Composite } \\
\text { Reliability }\end{array}$ & AVE \\
\hline \multirow{6}{*}{$\begin{array}{l}\text { Cognitive } \\
\text { Change }\end{array}$} & $\mathrm{CC} 1$ & 0.738 & \multirow{6}{*}{0.885} & \multirow{6}{*}{0.913} & \multirow{6}{*}{$\begin{array}{l}0.63 \\
7\end{array}$} \\
\hline & $\mathrm{CC} 2$ & 0.770 & & & \\
\hline & $\mathrm{CC} 3$ & 0.816 & & & \\
\hline & $\mathrm{CC} 4$ & 0.871 & & & \\
\hline & CC5 & 0.820 & & & \\
\hline & CC6 & 0.768 & & & \\
\hline \multirow{7}{*}{$\begin{array}{l}\text { Material } \\
\text { Change }\end{array}$} & $\mathrm{MC} 1$ & 0.696 & \multirow{7}{*}{0.878} & \multirow{7}{*}{0.906} & \multirow{7}{*}{$\begin{array}{l}0.58 \\
1\end{array}$} \\
\hline & MC2 & 0.683 & & & \\
\hline & MC3 & 0.772 & & & \\
\hline & MC4 & 0.798 & & & \\
\hline & MC5 & 0.845 & & & \\
\hline & MC6 & 0.857 & & & \\
\hline & MC7 & 0.660 & & & \\
\hline \multirow{10}{*}{$\begin{array}{l}\text { Perceptual } \\
\text { Change }\end{array}$} & PC1 & 0.746 & \multirow{10}{*}{0.925} & \multirow{10}{*}{0.936} & \multirow{10}{*}{$\begin{array}{l}0.59 \\
6\end{array}$} \\
\hline & PC10 & 0.801 & & & \\
\hline & $\mathrm{PC} 2$ & 0.733 & & & \\
\hline & PC3 & 0.853 & & & \\
\hline & PC4 & 0.861 & & & \\
\hline & PC5 & 0.772 & & & \\
\hline & PC6 & 0.644 & & & \\
\hline & PC7 & 0.785 & & & \\
\hline & PC8 & 0.774 & & & \\
\hline & PC9 & 0.726 & & & \\
\hline \multirow{14}{*}{$\begin{array}{l}\text { Relational } \\
\text { Change }\end{array}$} & $\mathrm{RC} 1$ & 0.777 & \multirow{14}{*}{0.964} & \multirow{14}{*}{0.969} & \multirow{14}{*}{$\begin{array}{l}0.69 \\
1\end{array}$} \\
\hline & $\mathrm{RC} 10$ & 0.894 & & & \\
\hline & $\mathrm{RC} 11$ & 0.937 & & & \\
\hline & $\mathrm{RC} 12$ & 0.925 & & & \\
\hline & $\mathrm{RC} 13$ & 0.919 & & & \\
\hline & $\mathrm{RC} 14$ & 0.919 & & & \\
\hline & $\mathrm{RC} 2$ & 0.762 & & & \\
\hline & $\mathrm{RC} 3$ & 0.787 & & & \\
\hline & $\mathrm{RC} 4$ & 0.793 & & & \\
\hline & RC5 & 0.691 & & & \\
\hline & RC6 & 0.647 & & & \\
\hline & $\mathrm{RC7}$ & 0.704 & & & \\
\hline & RC8 & 0.890 & & & \\
\hline & RC9 & 0.918 & & & \\
\hline
\end{tabular}

Validity of the Instrument is accessed through the measurement model on two major aspects namely convergent validity and discriminant validity. Convergent validity of the instrument can be inferred from the Average Variance Extracted (AVE) values which should be more than 0.5. Results from table2 shows that, all the constructs have an AVE value more than 0.5. Hence the constructs are free from Convergent validity issues. Yet another important validity namely Discriminant 
validity can be inferred from table 3 and table 4 which has outputs representing correlation, Square root of AVE, Factor loading and Cross loading values. As per Fornell and Larcker (1981), the diagonal elements which are the square root of AVE should be higher than the off-diagonal elements in the corresponding rows and columns. From table5 it is observed that, all the square root of AVE values is higher than the correlation values hence confirming the absence of discriminant validity issues.

Table3: Correlation and Square Root of AVE

\begin{tabular}{lllll}
\hline & $\mathbf{1}$ & $\mathbf{2}$ & $\mathbf{3}$ & $\mathbf{4}$ \\
\hline $\begin{array}{c}\text { 1.Cognitive } \\
\text { Change }\end{array}$ & $\mathbf{0 . 7 9 8}$ & & & \\
$\begin{array}{c}\text { 2.Material } \\
\text { Change }\end{array}$ & 0.533 & $\mathbf{0 . 7 6 2}$ & & \\
$\begin{array}{c}\text { 3.Perceptual } \\
\text { Change }\end{array}$ & 0.060 & 0.009 & $\mathbf{0 . 7 7 2}$ & \\
$\begin{array}{c}\text { 4.Relational } \\
\text { Change }\end{array}$ & 0.081 & 0.027 & 0.058 & $\mathbf{0 . 8 3 1}$ \\
\hline
\end{tabular}

\begin{tabular}{cllll} 
PC6 & -0.006 & -0.024 & 0.644 & 0.043 \\
PC7 & 0.039 & 0.036 & 0.785 & -0.034 \\
PC8 & 0.071 & 0.047 & 0.774 & 0.087 \\
PC9 & -0.080 & -0.004 & 0.726 & -0.029 \\
RC1 & 0.152 & 0.148 & 0.061 & 0.777 \\
RC10 & -0.043 & -0.129 & 0.019 & 0.894 \\
RC11 & -0.013 & -0.067 & 0.027 & 0.937 \\
RC12 & 0.005 & -0.055 & 0.028 & 0.925 \\
RC13 & 0.000 & -0.038 & 0.025 & 0.919 \\
RC14 & 0.000 & -0.038 & 0.025 & 0.919 \\
RC2 & 0.148 & 0.117 & 0.043 & 0.762 \\
RC3 & 0.230 & 0.111 & 0.085 & 0.787 \\
RC4 & 0.250 & 0.154 & 0.109 & 0.793 \\
RC5 & 0.142 & 0.196 & 0.154 & 0.691 \\
RC6 & 0.080 & 0.097 & 0.072 & 0.647 \\
RC7 & -0.074 & -0.067 & 0.000 & 0.704 \\
RC8 & -0.030 & -0.072 & -0.016 & 0.890 \\
RC9 & 0.020 & -0.074 & 0.025 & 0.918 \\
\hline & & & & \\
\hline
\end{tabular}

Source : Primary Survey

Note: Square root of AVE is mentioned across the diagonal.Source : Primary Survey

Table4 represents the factor loading and cross loading values of each item towards all the constructs. As per Partial Least Square literature, the items of a construct should have more loading value in its respective construct than the other constructs which will confirm the absence of discriminant validity issues. It is found that all the items have higher loadings in their respective constructs and hence possess discriminant validity.

Table4: Factor loadings and Cross loadings

\begin{tabular}{lllll}
\hline c & $\begin{array}{l}\text { Cognitive } \\
\text { Change }\end{array}$ & $\begin{array}{l}\text { Material } \\
\text { Change }\end{array}$ & $\begin{array}{l}\text { Perceptual } \\
\text { Change }\end{array}$ & $\begin{array}{l}\text { Relational } \\
\text { Change }\end{array}$ \\
\hline CC1 & 0.738 & 0.461 & -0.019 & 0.109 \\
CC2 & 0.770 & 0.375 & 0.073 & 0.087 \\
CC3 & 0.816 & 0.384 & 0.132 & 0.017 \\
CC4 & 0.871 & 0.484 & 0.035 & 0.024 \\
CC5 & 0.820 & 0.461 & 0.047 & 0.037 \\
CC6 & 0.768 & 0.378 & 0.026 & 0.108 \\
MC1 & 0.446 & 0.696 & 0.039 & 0.083 \\
MC2 & 0.266 & 0.683 & -0.058 & 0.008 \\
MC3 & 0.344 & 0.772 & 0.010 & -0.030 \\
MC4 & 0.401 & 0.798 & -0.016 & -0.060 \\
MC5 & 0.360 & 0.845 & 0.005 & 0.048 \\
MC6 & 0.533 & 0.857 & -0.018 & -0.015 \\
MC7 & 0.429 & 0.660 & 0.062 & 0.080 \\
PC1 & 0.019 & -0.071 & 0.746 & 0.024 \\
PC10 & 0.043 & 0.017 & 0.801 & 0.140 \\
PC2 & 0.007 & -0.057 & 0.733 & 0.017 \\
PC3 & 0.092 & -0.041 & 0.853 & 0.039 \\
PC4 & -0.043 & -0.014 & 0.861 & 0.054 \\
PC5 & 0.176 & 0.103 & 0.772 & -0.025 \\
\hline & & & &
\end{tabular}

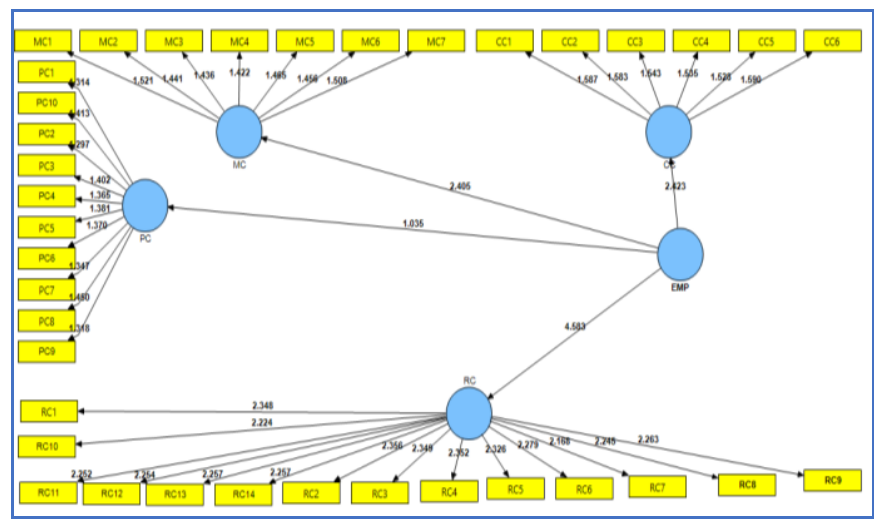

Figure 2: Structural Model- Empowerment

Source : Primary Survey

Once the constructs are validated, the path between the constructs, which is refereed as inner model/structural model as per smart-pls can be accessed using the Bootstrapping method. Through bootstrapping method 5000 sub samples were drawn and the paths were validated using the t-value. The obtained t-value should be more than 1.96 in order to confirm the path between an exogenous and exogenous construct as valid. Table5 reveals that, all the path from the exogenous and the endogenous constructs were valid at 5\% level of significance. Among all the paths, the path from Empowerment towards Relational Change (0.823) was found to be the highest followed by the path from Empowerment towards Cognitive Change (0.548), Empowerment towards Material Change (0.491) and Empowerment towards Perceptual Change (0.2224). 
Table5: Path Co-efficient and t-value

\begin{tabular}{lccccccc}
\hline & $\begin{array}{c}\text { Original } \\
\text { Sample } \\
(\mathbf{O})\end{array}$ & $\begin{array}{c}\text { Sample } \\
\text { Mean } \\
(\mathbf{M})\end{array}$ & $\begin{array}{c}\text { Standard } \\
\text { Deviation } \\
(\text { STDEV })\end{array}$ & $\begin{array}{c}\text { Standard } \\
\text { Error } \\
(\text { STERR })\end{array}$ & $\begin{array}{c}\text { T Statistics } \\
(\mid \mathbf{O} / \text { STERR })\end{array}$ & $\begin{array}{c}\text { Path. } \\
\text { Sig }\end{array}$ \\
\hline Empowerment -> Cognitive Change & 0.5476 & 0.5264 & 0.226 & 0.226 & 2.4229 & Yes \\
Empowerment -> Material Change & 0.4911 & 0.5246 & 0.2042 & 0.2042 & 2.4051 & Yes \\
Empowerment -> Perceptual Change & 0.2224 & 0.3534 & 0.2149 & 0.1049 & 2.1201 & Yes \\
& & & & & & \\
Empowerment -> Relational Change & 0.8249 & 0.7722 & 0.18 & 0.18 & 4.5833 & Yes \\
\hline
\end{tabular}

\section{Source : Primary Survey}

Multi group analysis techniques helps in finding whether the pre-defined data have significant difference across group. In this study, a multigroup analysis is made on the overall model based on two groups namely Karnataka and Goa. The table above shows that, except the path between Material Change and Empowerment all the other paths does not have any significant difference among the respondents based on type of State. It was found that the path co-efficient value for Karnataka (0.485) seems to be higher than the path co-efficient value for Goa (0.326).

Table6: Multi Group Analysis

Source : Primary Survey

\begin{tabular}{|c|c|c|c|c|c|c|c|}
\hline & $\begin{array}{l}\text { Group. } \\
\text { Karnataka }\end{array}$ & $\begin{array}{l}\text { Group. } \\
\text { Goa }\end{array}$ & diff.abs & t.stat & deg.fr & p.value & sig.05 \\
\hline Material->Empowerment & 0.4848 & 0.3259 & 0.1589 & 2.5297 & 261 & 0.006 & yes \\
\hline Cognitive->Empowerment & 0.3191 & 0.3583 & 0.0392 & 0.7317 & 261 & 0.2325 & no \\
\hline Perception->Empowerment & 0.319 & 0.385 & 0.066 & 0.5184 & 261 & 0.3023 & no \\
\hline Relational->Empowerment & 0.5896 & 0.5903 & 0.0008 & 0.1249 & 261 & 0.4504 & no \\
\hline
\end{tabular}

an extent affected the accuracy of the study.

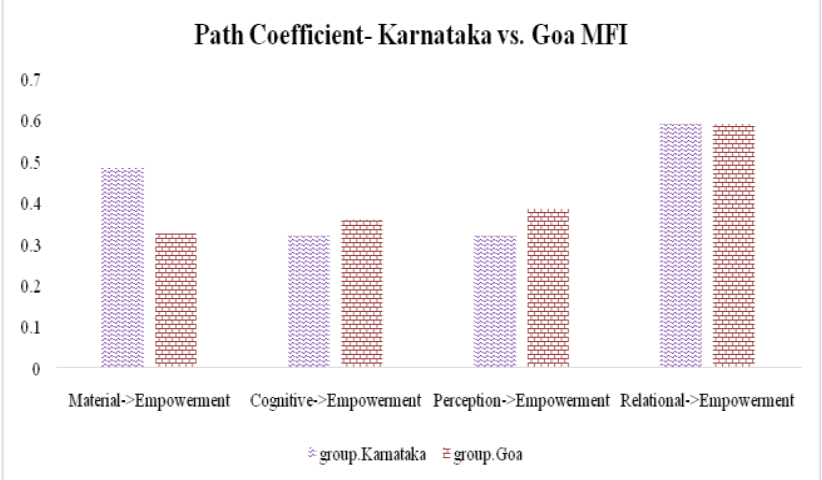

Source : Primary Survey

\section{LIMITATIONS OF THE STUDY}

With the samples drawn from only some parts of Goa and Karnataka, the results may not be appicable to areas with different geographical and social backgrounds. The study may further miss out on the influence of microcredit on empowerment of women. Also, respondents may have refrained from sharing important information due to many reasons and this may have to

\section{REFERENCES}

1. Afrane.S (2005), Impact assessment in Ghana and South Africa: A synthesis of major impacts and lessons, Journal of microfinance, Vol 4, Number, PP 38-58

2. Batliwala.S.(1994), The meaning of women's empowerment: New concepts from action in sen, Mayoux.L. (2006), Sustainable microfinance for women's empowerment strategy checklists, genfinance website http://www.genfinance.info

3. Bharat Dogra (2002), Women self-help group, Kurukshetra, Volume 50, No 5, March 202, Pp 40,42

4. Barik BB \&Vannan PP (2001), Promoting self help groups as sub system of credit cooperatives, The cooperator, Volume, 38, No 7, January, Pp 305-11

5. Cheston S and Kunh L (2002), Empowering women through microfinance, draft paper prepared for women's opportunity fund and its funding partners.

6. Chiranjeevulu T (2003), Empowering women through self help groups, kurukshetra, volume 51, No 5, March, Pp. 16-19

7. Friedmann (1992), Empowerment: The politics of alternative development, Blackwell publishers, Oxford University press.

8. Fornell, C \&Larcker, D 1981, 'Evaluating Structural Equation Models with Unobservable Variables and Measurement Error', Journal of Marketing Research, vol. 18, no. 3, pp. 39-50.

9. Germaine and Chen - Population policies reconsidered : Health empowerment and rights. Harvard University Press.

10. Hulland, J. S. (1999). Use of partial least squares (PLS) in strategic management research: A review of four recent studies. 
Strategic Management Journal, 20(4), 195-204.

11. Hilvoet N (2005), the impact of microfinance on decision making agency: Evidence from South India, Development \& Change Volume 36(1) PP 75-102

12. Hair, JFJ, Hult, GTM, Ringle, C \&Sarstedt, M 2014, A Primer on Partial Least Squares Structural Equation Modeling (PLS-SEM). Long Range Planning.

13. Johnson.S. (2005), Gender relations, empowerment and microcredit: Moving on from lost decade, the European journal of Development research, Vol 17, No.2 pp 224-248

14. Kabeer, N. (1998). Can't buy me love? Re-evaluating gender, credit and empowerment in rural Bangladesh.IDS Discussion Paper No. 363. Institute of DevelopmentStudies, Sussex.

15. Kabeer, N. (1999). Resources, agency, achievement:reections on the measurement of women's empowerment. Development and Change, $30(3), 435 \pm 464$

16. Kabeer, N. (2000). The power to choose: Bangladeshi women and labour market decisions in London and Dhaka. London: Verso.

17. Lakwo A (2006), Microfinance, rural livelihoods and women empowerment in Uganda, African studies centre, research report 85.

18. Moser.C.(1993) Gender planning and development: theory, practice and training, routledge, London.

19. Mahmud.S (2003), Actually how empowering is microcredit? Development and change, Vol 34, issue 4, Page: 577-605

20. Nunnally, J. O. (1978). Psychometric Theory (New York: McGraw-Hill).

21. Om Raj singh (2003), Role of NGO's in fostering self help groups, Kurukshetra, Volume 51. No.4 Februrary, Pp.33-35

22. Ohja R K (2001) self help groups and rural employment yojana, volume, 45, May, Pp. 20-23 [25] PrashanthSarangi (2003), Self help groups, Kurukshetra, Volume,51, No 4, February, Pp.33-35

23. Osmani L (2007), A breakthrough in women's bargaining power: the impact of microcredit, Journal of International development, Chicester, Vol 19, PP 695-702

24. Oxaal.Z and baden.S.(1997) Gender and Empowerment: Definition, approaches and implication for policy, Bridger institute of development studies, Swiss international development corporation SIDA.

25. Price J (1992), Women's development: welfare projects or political empowerment? Amsterdam conference, mimeo.

26. RolandsJ(1997), Questioning empowerment: working with women in Honduras. Oxford:Oxfam

27. Rajamohan S (2003), Activities of self help groups in virudhunagar district - A study cooperation, Volume 3, No. 6, April, Pp.15-17

28. Sullivan.O.(2004), Changing gender practices within the household : theoretical perspective gender and society 18,2:207- 222

29. Swain R \&Wallentin.Y (2008), Economic and non-economic factors- what empowers women? Working paper 2008:11, Department of Economics, Uppsala University, Sweden.

30. Shanthi G and Dhanalakhmi C.,(2004) Case study of women empowerment through self help groups in Gobichettipalayam block - Erode district, Cooperation Volume 4, No 4 August, 2004 Pp 23-25

31. Shankar chatterjee (2003), Networking SGSY, Banks and SHG's, Kurukshetra, Volume 51, No 5, March, pp.27-35

32. Sivaramakrishnan K (2003), Poverty alleviation through self help groups, cooperation, Volume 3, No 5, March, Pp8-14

33. Thakrar K (2006), Rags to riches of fortunes to fists? Microfinance and gendered intra house hold conflict in India. Dissertation, London school of Economics.

34. Vijay D Kulkarni (2001), Empowerment of women through Self help groups, Ashwatha, Volume 3\&4, No 1-2, 4., October,2000 June. PP 32-36

35. Velu Suresh kumar (2005), Women empowerment, Success through self help groups, Kisan world, volume 32, No 11, November,p31 